\title{
Lung Non-Small Cell Cancer by AJCC v7 Stage
}

National Cancer Institute

\section{Source}

National Cancer Institute. Lung Non-Small Cell Cancer by A/CC v7 Stage. NCI Thesaurus.

Code C136491.

A term that refers to the staging of non-small cell lung carcinoma, following the rules of the TNM AJCC v7 classification system. 